\title{
Multiple Potential Plant Growth Promotion Activities of Endemic Streptomyces spp. from Moroccan Sugar Beet Fields with Their Inhibitory Activities against Fusarium spp.
}

\author{
Yassine Aallam ${ }^{1}$, Bouchra El Maliki ${ }^{2}$, Driss Dhiba ${ }^{3} \mathbb{D}^{\mathbb{D}}$, Sanaa Lemriss ${ }^{1,4} \mathbb{D}^{\mathbb{D}}$, Amal Souiri $^{4} \mathbb{D}_{\text {, }}$ \\ Abdelmajid Haddioui ${ }^{1}$, Mika Tarkka ${ }^{5}$ and Hanane Hamdali ${ }^{1, *}$ (D) \\ 1 Laboratory of Biotechnology and Valorization of Plant Genetic Resources, Faculty of Sciences and Technology, \\ University of Sultan Moulay Slimane, P.O. 523, Beni-Mellal 23000, Morocco; yassine.aallam@gmail.com (Y.A.); \\ slemriss@lram-fgr.ma (S.L.); ahaddioui@yahoo.fr (A.H.) \\ 2 Faculty of Medecine and Pharmacy, University Hassan II, Casablanca 20250, Morocco; b.elmaliki@gmail.com \\ 3 International Water Research Institute (IWRI), Moulay Rachid, University Mohammed 6 Polytechnic (UM6P), \\ Ben Guerir 43150, Morocco; driss.dhiba@um6p.ma \\ 4 Laboratory of Research and Medical Analysis of Gendarmerie Royale, Department of Biosafety PCL3, \\ Rabat 10090, Morocco; asouiri@lram-fgr.ma \\ 5 UFZ-Helmholtz-Centre for Environmental Research, Soil Ecology Department, Theodor-Lieser-Straße 4, \\ 06120 Halle, Germany; mika.tarkka@ufz.de \\ check for \\ * Correspondence: hanane.hamdali@usms.ac.ma; Tel.: +212-523485112; Fax: +212-523485201
} updates

Citation: Aallam, Y.; Maliki, B.E.; Dhiba, D.; Lemriss, S.; Souiri, A.; Haddioui, A.; Tarkka, M.; Hamdali, H. Multiple Potential Plant Growth Promotion Activities of Endemic Streptomyces spp. from Moroccan Sugar Beet Fields with Their Inhibitory Activities against Fusarium spp.. Microorganisms 2021, 9, 1429. https://doi.org/10.3390/ microorganisms 9071429

Academic Editors: Pedro M. Santos and Pedro Castro

Received: 19 May 2021

Accepted: 11 June 2021

Published: 2 July 2021

Publisher's Note: MDPI stays neutral with regard to jurisdictional claims in published maps and institutional affiliations.

Copyright: () 2021 by the authors. Licensee MDPI, Basel, Switzerland. This article is an open access article distributed under the terms and conditions of the Creative Commons Attribution (CC BY) license (https:// creativecommons.org/licenses/by/ $4.0 /)$.

\begin{abstract}
The characterized 10 Streptomyces isolates were previously selected by their abilities to solubilize phosphates. To investigate whether these isolates represent multifaceted plant growthpromoting rhizobacteria (PGPR), their potassium-solubilizing, auxin-producing and inhibitory activities were determined. The 10 Streptomyces spp. yielded a variable biomass in the presence of insoluble orthoclase as the sole potassium (K) source, indicating that they were able to extract different amounts of $\mathrm{K}$ from this source for their own growth. Three strains (AZ, AYD and DE2) released soluble $\mathrm{K}$ from insoluble orthoclase in large amounts into the culture broth. The production levels ranged from $125.4 \mathrm{mg} / \mathrm{L}$ to $216.6 \mathrm{mg} / \mathrm{L}$ after 5 days of culture. Only two strains, Streptomyces enissocaesilis (BYC) and S. tunisiensis (AI), released a larger amount of soluble $\mathrm{K}$ from orthoclase and yielded much more biomass. This indicated that the rate of $\mathrm{K}$ released from this insoluble orthoclase exceeded its consumption rate for bacterial growth and that some strains solubilized $\mathrm{K}$ more efficiently than others. The results also suggest that the K solubilization process of AZ, AYD and DE2 strains, the most efficient K-solubilizing strains, involves a slight acidification of the medium. Furthermore, these 10 Streptomyces spp. were able to secrete indole acetic acid (IAA) in broth medium and ranged from $7.9 \pm 0.1 \mu \mathrm{g} / \mathrm{mL}$ to $122.3 \pm 0.1 \mu \mathrm{g} / \mathrm{mL}$. The results of the antibiosis test proved the potential of the 10 tested strains to limit the growth of fungi and bacteria. In dual culture, S. bellus (AYD) had highest inhibitory effect against the three identified fungal causal agents of root rot of sugar beet: Fusarium equiseti and two F. fujikuroi at 55, 43 and 36\%, respectively. Streptomyces enissocaesilis (BYC), S. bellus (AYD) and S. saprophyticus (DE2) exhibited higher multifaceted PGPR with their potassium-solubilizing, auxin-producing and inhibitory activities, which could be expected to lead to effectiveness in field trials of sugar beet.
\end{abstract}

Keywords: Streptomyces spp.; potassium solubilization; orthoclase; biocontrol; root rot; sugar beet

\section{Introduction}

One of the most commonly cultivated plants used in the sugar industry is sugar beet (Beta vulgaris L.). Production of sugar from this crop is the second largest in the world after production from sugar cane [1], but sugar beet is more resilient, coping with less favorable environmental conditions than sugar cane [2]. In Morocco, sugar beet occupies an area of 57,171 hectares with a production of 3.7 million tons in 2019 [3]. The Beni Mellal- Khenifra 
region (east of Casablanca), located in a vast agricultural plain in Morocco, represents $26 \%$ of the national production with an area of 15,000 hectares [4], and contributes $20.5 \%$ and $21.2 \%$ to the national area and production of sugar beet in Morocco, respectively [5].

Sugar beet requires balanced fertilization by the three macronutrients, nitrogen $(\mathrm{N})$, phosphorus (P) and potassium (K). Potassium is one of the most important elements for sugar beet nutrition and plays a significant role in enzyme activation, charge balance, osmoregulation and reduction in the negative effects of drought stress [6,7]. In sugar beet, $\mathrm{K}$ is also involved in biosynthesis and transfer of sucrose to storage roots [8]. Hanafy et al. [9] found that the application of K significantly improved root yield, length, diameter and fresh root weight of sugar beet. Additionally, many studies have reported that $\mathrm{K}$ and $\mathrm{N}$ enhance the biosynthesis of organic metabolites which increase the yield and quality of sugar beet [10]. In soil, $\mathrm{K}$ is a mineral element which represents a minor soluble part, ranging from 1.00 to $1.5 \times 10^{-3} \mathrm{mmol} / \mathrm{L}$, and is thus unavailable for plant uptake [11]. In soil, potassium ( $98 \%$ ) exists in the form of silicate minerals (orthoclase, feldspars, muscovite, microline, etc.) [12].

In contrast to the well-documented action of phosphate-solubilizing and nitrogenfixing microorganisms in plant $\mathrm{P}$ and $\mathrm{N}$ nutrition $[13,14]$, the importance of microbial activity on plant $\mathrm{K}$ nutrition is less well understood. It has been shown that bacteria and mycorrhizal fungi do solubilize mineral $\mathrm{K}$ by various mechanisms such as production of alkaline substances including ammonia and other metabolites upon death of microbial cells and subsequent proteolysis $[15,16]$. K-solubilizing bacteria (KSB) have attracted more attention because of their ability to increase plant growth and yield [17]. However, very few studies have demonstrated these abilities of KSB [18-23]. To date and to the best of our knowledge, this is the first time that such a study has been undertaken, especially on the endemic Actinobacteria from sugar beet rhizospheres in the Beni-Mellal region with these PGPR criteria.

As in all plants, sugar beets are parasitized by a number of fungi that are able to attack one or more of their organs, reducing their growth and the reserves accumulated in roots. Rhizoctonia solani represents one of the major constraints in the production of sugar beets around the world [24] and is the main cause of various plant diseases, especially root rot [25]. Fusarium sp. is another damaging agent of sugar beet, causing root rot [26-28]. Plants infected with Fusarium spp. show early symptoms: the color of the leaves turns yellow and they die, the petioles also wilt around the crown and the root yield and the percentage of sucrose are reduced [29]. Moreover, Rhizoctonia crocorum, Phoma betae, Aphanomyces cochlioides, Macrophomina phaeseolina, Pythium aphanidermatum, Phytophthora drechsleri, Sclerotium rolfsii and Rhizopus stolonifer are also causative agents of root rot of sugar beets [30,31].

Actinobacteria are known by the production of phytohormones such as ethylene, gibberellic acid, indole-3-acetic acid (IAA), cytokines and ACC deaminases [32-35]. Moreover, Actinomycetes can have antimicrobial activities and effects against phytopathogens [36-38]. From the 10,000 antimicrobial molecules produced by Actinomycetes, more than $50 \%$ were isolated from Streptomycetes [39].

Therefore, this research aimed to assess if the 10 strongly P-solubilizing strains of Streptomyces of the sugar beet rhizosphere in Beni-Mellal [40] possess multifaceted PGPR activities, and tested their abilities to solubilize $\mathrm{K}$ from insoluble orthoclase, produce auxins and inhibit sugar beet root pathogens in laboratory conditions. Through these experiments, we expected to identify the most effective strains of the collection for future field trials.

\section{Materials and Methods}

\subsection{Actinomycete Strains}

Ten selected Actinomycete strains used in this study were isolated from three different sugar beet rhizospheres that were previously selected for their abilities to solubilize insoluble phosphate forms (a Moroccan natural rock phosphate and a synthetic tricalcium phosphate) using the SMM medium and to produce siderophores [40]: AYD, AZ, AV and 
BX related to Streptomyces bellus; BYC: Streptomyces enissocaesilis; AI: Streptomyces tunisiensis; BP: Streptomyces coerulescens; CYM: Streptomyces cyaneofuscatus; DE1: Streptomyces bellus and DE2: Streptomyces saprophyticus. Spores of the selected Actinomycete isolates were stored in $20 \%$ sterile glycerol at $-20^{\circ} \mathrm{C}$ for the next tests.

\subsection{Actinomycete Abilities to Use Orthoclase as Sole Potassium Source}

Potassium solubilization by the 10 Actinomycete strains was carried out on modified Aleksandrov agar medium (AMM) [41], containing $5.0 \mathrm{~g} / \mathrm{L}$ glucose, $0.5 \mathrm{~g} / \mathrm{L} \mathrm{MgSO} 4 \cdot 7 \mathrm{H}_{2} \mathrm{O}$, $0.1 \mathrm{~g} / \mathrm{L} \mathrm{CaCO}_{3}, 0.006 \mathrm{~g} / \mathrm{L} \mathrm{FeCl}_{3}, 2.0 \mathrm{~g} / \mathrm{L} \mathrm{Na}_{2} \mathrm{HPO}_{4}$ and orthoclase powder $(2.0 \mathrm{~g} / \mathrm{L})$ [42] as a unique $\mathrm{K}$ source, or on AMM containing soluble $\mathrm{K}_{2} \mathrm{HPO}_{4}(0.5 \mathrm{~g} / \mathrm{L})$ as a positive control or no $\mathrm{K}$ source as a negative control. After plating, the agar plates were incubated for 21 days at $28^{\circ} \mathrm{C}$ in order to allow growth of the slow-growing Actinomycetes.

\subsection{Quantitative Estimation of the Amount of Solubilized Potassium by the Selected Actinomycete Strains}

Three different tests with $10^{6}$ spores $/ \mathrm{mL}$ of each of the ten selected Actinomycete strains were inoculated in $250 \mathrm{~mL}$ Erlenmeyer flasks containing $50 \mathrm{~mL}$ of liquid AMM with $2 \mathrm{~g} / \mathrm{L}$ of orthoclase as the sole natural $\mathrm{K}$ source were carried out in triplicate, and the cultures were grown for 5 days at $28 \pm 2{ }^{\circ} \mathrm{C}$ on a rotary shaker $(180 \mathrm{~g} / \mathrm{min})$ [41]. Every day, a $1 \mathrm{~mL}$ aliquot of each culture was taken and centrifuged at $10,000 \times g$ for $10 \mathrm{~min}$, and dry biomass and the $\mathrm{pH}$ of the supernatant were determined. The supernatant was analyzed for soluble K content by inductively coupled plasma atomic emission spectroscopy according to Liu et al. [43]. Similar measures were carried out in non-inoculated flasks incubated in the same conditions.

\subsection{Assay for Indole Acetic Acid (IAA) Production}

The production of IAA was evaluated on liquid Luria-Bertani (LB) medium supplemented with L-tryptophan (Merck, Darmstadt, Germany) $(1 \mathrm{~g} / \mathrm{L})$ [44]. The growth medium used contained tryptone (Merck) (10 g); yeast extract (Merck) (5 g); $\mathrm{NaCl}(5 \mathrm{~g})$ in $1 \mathrm{~L}$ of deionized water. This medium was sterilized at $121^{\circ} \mathrm{C}$ for $20 \mathrm{~min}$. Sterilized tubes containing $10 \mathrm{~mL}$ of the medium were inoculated with $20 \mu \mathrm{L}$ of actinobacterial cultures $\left(10^{7} \mathrm{cfu} / \mathrm{mL}\right)$ and incubated at $28{ }^{\circ} \mathrm{C}$ for $72 \mathrm{~h}$ with moderate stirring at $130 \mathrm{rpm} / \mathrm{min}$. The determination of the IAA concentration was carried out by the addition of $2 \mathrm{~mL}$ of Salkowski's reagent $\left(2 \%(w / v) 0.5 \mathrm{M} \mathrm{FeCl}_{3}\right.$ in $35 \%$ perchloric acid) to $1 \mathrm{~mL}$ of the culture supernatant previously centrifuged for $10 \mathrm{~min}$ at $10,000 \times \mathrm{g}$. A pink color indicated the presence of IAA. The IAA concentration produced was estimated by measuring the OD at $530 \mathrm{~nm}$ after $30 \mathrm{~min}$ of incubation in the dark [45]. The concentration of IAA produced by each Actinomycete strain was determined by the generation of a standard curve.

\subsection{Isolation of Fungi from Symptomatic Sugar Beet Roots}

Filamentous fungi were collected during a sugar beet harvesting campaign in June 2020. The contaminated sugar beet site was located $25 \mathrm{~km}$ from Beni Mellal city $\left(32^{\circ} 29^{\prime} 34.2^{\prime \prime}\right.$ N 6 $10^{\prime} 56.1^{\prime \prime} \mathrm{W}$, center of Morocco). This infected site has a warm Mediterranean climate with a temperature ranging between 1.1 and $40{ }^{\circ} \mathrm{C}$ and a mean annual rainfall generally between 350 and $650 \mathrm{~mm} /$ year [46]. In sterile plastic bags, roots with symptoms of damage and fungi infection were harvested and isolated aseptically (Figure 1).

According to the modified protocol of Chenaoui et al. [47], the surface soil of contaminated sugar beet root was removed. To cultivate rhizoplane fungi that may be associated with the root symptoms and interact with rhizosphere Streptomycetes, the mycelium on the root surface was scraped off with a sterile platinum loop and plated on potato dextrose agar (PDA) medium (Merck, France). The PDA medium used contained potato infusion $(4 \mathrm{~g})$, dextrose $(20 \mathrm{~g})$ and agar $(17 \mathrm{~g})$ in $1 \mathrm{~L}$ of deionized water at a final $\mathrm{pH}$ of $5.6 \pm 0.2$. Plates were incubated in the dark at $26 \pm 2{ }^{\circ} \mathrm{C}$ for $7-8$ days and checked every day. Hyphae were purified and preserved on PDA medium for further study. 


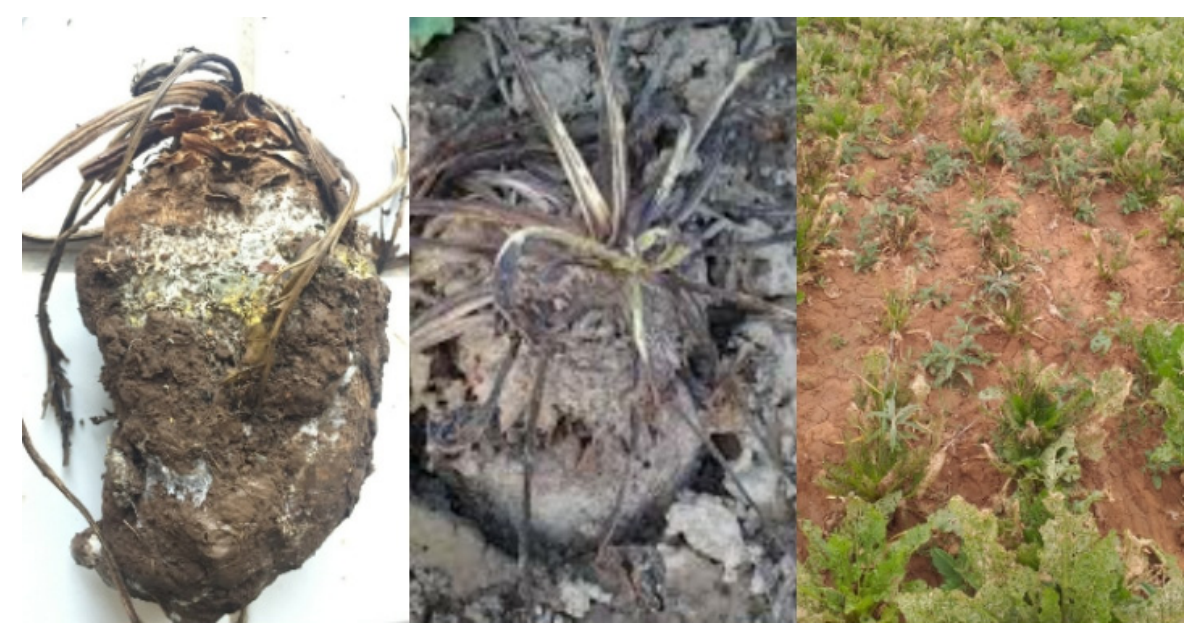

Figure 1. Symptomatic sugar beet roots and field with the isolated Fusarium spp. causal agent of root rot disease in Beni Mellal, Morocco.

\subsection{Molecular Determination of Isolated Fungi (DNA Extraction and ITS Amplification)}

Preliminary identification of the three selected fungi (CHAMP1, CHAMP2 and CHAMP3) was performed by microscopic observation of the plates with lacto phenol blue, direct examination with $20 \% \mathrm{KOH}$ Chinese ink and by description of the macroscopic features of colonies after a period of incubation of eight to ten days at $25^{\circ} \mathrm{C}$.

For molecular identification, fungal DNA was isolated from pure cultures on Sabouraud agar medium of three selected isolates. Approximately $1 \mathrm{~cm}^{2}$ of mycelium was collected and added to an Eppendorf tube containing $1 \mathrm{~mL}$ of distilled water and 12 to 15 glass beads with a diameter of $3 \mathrm{~mm}$ (Merck). After vortexing at maximum speed for $2 \mathrm{~min}, 300 \mu \mathrm{L}$ of the suspension containing fragmented mycelium was used for automated extraction of DNA with the Maxwell ${ }^{\circledR}$ RSC Instrument (Promega, Madison, WI, USA) and the Maxwell RSC PureFood GMO and Authentication Kit (Promega) according to the manufacturer's instructions. The nuclear ribosomal ITS1-5.8S-ITS2 region was amplified with the universal primers ITS1 (5'-CCGTAGGTGAACCTGCGG-3') and ITS4 (5'-TCCTCCGCTTATTGATATGC-3') [48]. The nuclear rDNA segment corresponding to the D2 region of the fungal 28S ribosomal RNA (28S-D2 rDNA) was amplified with the primers NL1 (5'-GCATATCAATAAGCGGAGGAAAAG-3') and NL4 (5' GGTCCGTGTTTCAAGACGG-3') [49]. The 18S ribosomal RNA region was amplified with the primers FR1 (5'-ANC CAT TCA ATC GGT ANT-3 $\left.{ }^{\prime}\right)$ and FF390 (5'-CGA TAA CGA ACG AGA CCT-3') [48].

Amplifications were carried out in a $25 \mathrm{~mL}$ reaction mixture containing $5 \mu \mathrm{L}$ of PuRe Taq Ready-To-Go PCR Mix (GE Healthcare, Little Chalfont, UK), 4.5 pmoL of each primer, $9.1 \mu \mathrm{L}$ of water and $50 \mathrm{ng}$ of DNA. PCR conditions were as follows: after initial denaturation $\left(95^{\circ} \mathrm{C}\right.$ for $\left.3 \mathrm{~min}\right), 45$ cycles of $95^{\circ} \mathrm{C}$ for $1 \mathrm{~min}, 54^{\circ} \mathrm{C}$ for $1 \mathrm{~min} \mathrm{~s}$ and $72{ }^{\circ} \mathrm{C}$ for $2 \mathrm{~min}$, followed by a final extension $\left(7 \mathrm{~min}, 72^{\circ} \mathrm{C}\right)$. All amplifications were carried out using a GeneAmp PCR 9700 System (Applied Biosystems). Negative controls were included with no addition of template DNA. PCR products were visualized on a $\%(w / v)$ agarose gel stained with ethidium bromide. The nuclear ribosomal ITS1-5.8S-ITS2 region, $28 \mathrm{~S}$ ribosomal RNA region and $18 \mathrm{~S}$ ribosomal RNA region were sequenced bidirectionally with primers ITS1 and ITS4, NL1 and NL4, and FR1 and FF390, respectively.

Sequences similarities were performed against corresponding sequences of Fusarium species using GenBank through Nucleotide BLAST (http:/ / www.ncbi.nlm.nih.gov/ BLAST / (accessed on 3 April 2021)). An unrooted phylogenetic tree was inferred using the neighbor-joining method [50]. The percentage of replicate trees in which the associated taxa clustered together in the bootstrap test (1000 replicates) is shown next to the branches [51]. The evolutionary distances were computed using the Kimura 2-parameter method [52] and 
are in the units of the number of base substitutions per site. Evolutionary analyses were conducted in MEGA X [53].

\subsection{In Vitro Antagonistic Activity Assays}

The plate diffusion method was used to assess the wide-spectrum antimicrobial activity of the 10 selected strains [54] against the following Gram-negative bacteria: Escherichia coli CCMM/B4 and Pseudomonas aeruginosa CCMM/B90, Klebsiella pneumonia E40, Salmonella sp. CCMM/B17; the following Gram-positive bacteria: Bacillus subtilis ATCC 9524, Staphylococcus aureus CCMM/B2, Streptococcus sp. CCMM/B24; and the yeast Candida albicans CCMM/L11 (all strains from the collection of BVRP Laboratory, USMS Beni Mellal) and three fungi isolated from the infected field of sugar beet rhizospheres, Beni Mellal, Morocco, as described above. These 10 selected Streptomyces spp. were grown on solid SMM [55] for 14 days and then three disks (diameter $10 \mathrm{~mm}$ ) were cut out and placed on lawns grown for $48 \mathrm{~h}$ of the different microorganisms on nutrient agar (Difco, Sparks, MD, USA) for bacteria and yeast. Plates were first stored at $-4{ }^{\circ} \mathrm{C}$ for at least $2 \mathrm{~h}$ to allow the diffusion of any substances produced, and then incubated at $28^{\circ} \mathrm{C}$. Sizes of the inhibition zones were determined after $24 \mathrm{~h}$ of incubation for bacteria and yeast. Controls involved the use of sterile agar plugs. Three replicates were performed for each isolate in each microorganism test.

For fungi, we followed the technique of dual culture from Karimi et al. [56], which was slightly modified. Briefly, disks of $10 \mathrm{~mm}$ in diameter from 5-day-old cultures of fungi were placed in the center of Sabouraud agar plates and the disks of tested Actinomycete strains were placed on either side of Sabouraud plates at a distance of $2.5 \mathrm{~cm}$. After 5 days of incubation at $28{ }^{\circ} \mathrm{C}$, the diameter of propagation of the fungi was recorded and the percentage of inhibition $(\mathrm{PI})$ was calculated: $\mathrm{PI}=[(\mathrm{T}-\mathrm{S}) / \mathrm{T}] \times 100$; where $\mathrm{T}$ represents the mycelial colony radius $(\mathrm{mm})$ of a control culture and $S$ represents the mycelial colony radius of the fungus in the presence of the Streptomyces strain [40].

\subsection{Statistical Analysis and Detection of the Most Promising Strains for Simultaneous Biofertilizer and Biocontrol Applications}

All experimental results were subjected to analysis of variance (ANOVA) using SPSS statistical software, version 23.0 (IBM, New York, NY, USA). The results were expressed as mean \pm SD. The means were compared using the least significant difference (LSD) test. $p<0.05$ indicates significant differences. To select the most promising Streptomycete isolates for combined biofertilizer and biocontrol applications, their relative activities in rock phosphate and tricalcium phosphate and of potassium solubilization, antifungal activity against Fusarium spp., antibacterial activity and production of IAA and siderophores were cross-compared between the strains and used to grade them from 1 (lowest) to 10 (highest activity). In order to achieve the aim of selecting combined biofertilizer and biocontrol agents, the rating values for rock phosphate and potassium solubilization, IAA production and Fusarium inhibition were weighted by 2 (doubled).

\section{Results}

\subsection{Growth Kinetics of the Selected Actinomycete Strains in AMM + Orthoclase}

The ten tested Actinomycete strains exhibit clear development on solid AMM with orthoclase as the sole potassium source. Figure 2 shows that the growth kinetics of most strains was variable from strain to strain. This indicated that the strains were able to assimilate variable amounts of potassium from these insoluble K sources, with a different efficiency, and use it for their own growth. The only exceptions were the strains BYC and AI that showed a better growth on AMM + orthoclase. In mainly AMM + orthoclase, all strains yielded a lower biomass at day 5 than at day 4, suggesting cell lysis. However, the biomass yield was not the same for all strains and the strains could be grouped into three classes: class I with biomass yield $\geq 600 \mu \mathrm{g} / \mathrm{mL}$ (BYC and AI), class II with biomass yield 
between 300 and $600 \mu \mathrm{g} / \mathrm{mL}$ (AZ, DE1, BP, CYM, DE2, AV and AYD) and class III with biomass yield below $200 \mu \mathrm{g} / \mathrm{mL}$ (BX strain) (Figure 2).

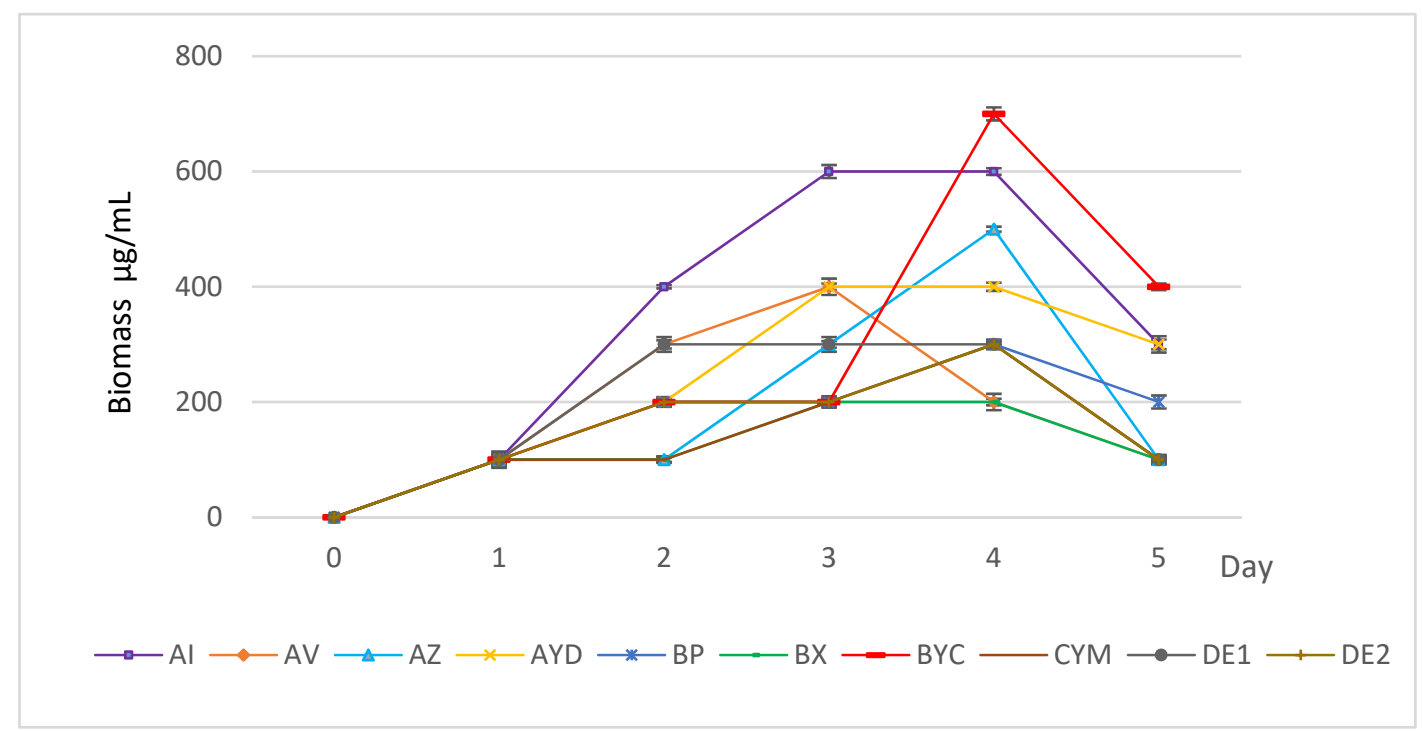

Figure 2. Evolution of the biomass of the selected Actinomycete strains grown in the liquid AMM + orthoclase. Error bars represent standard deviations of the mean values of the results of three independent culture replicates.

\subsection{Estimation of the Amount Soluble Potassium Released from Orthoclase by the Selected Actinomycete Strains}

The concentration of soluble $\mathrm{K}$ in the supernatant of all 10 selected Streptomyces strains from the sugar beet rhizospheres was assessed (Figure 3).

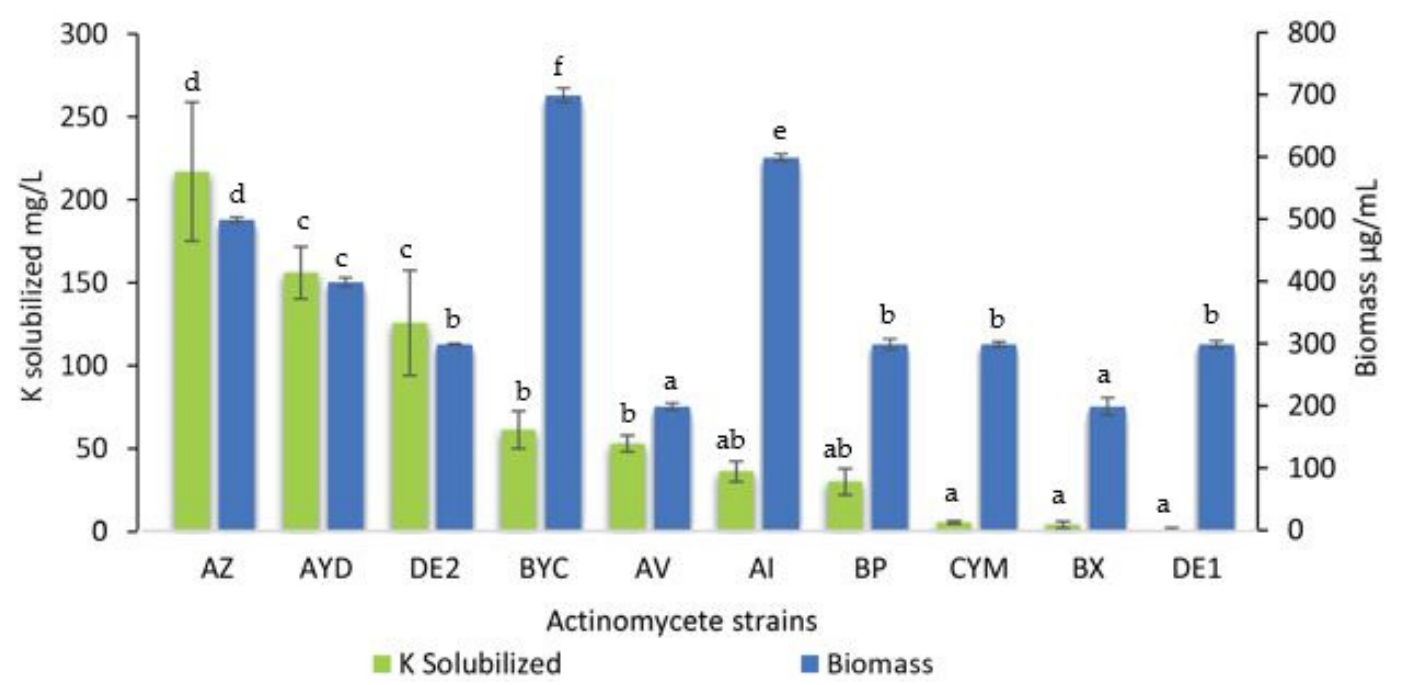

Figure 3. Concentration of soluble potassium released $(\mathrm{mg} / \mathrm{L})$ from orthoclase in the supernatant of cultures of the ten selected Actinomycete strains (green bars) grown for five days in AMM containing $2 \mathrm{~g} / \mathrm{L}$ orthoclase with values subtracted from those of the non-inoculated flasks. The maximal biomass yield in $\mu \mathrm{g} / \mathrm{mL}$ of the 10 selected Actinomycete strains is shown in the histogram (blue bars). Error bars represent standard deviations of the mean values of the results of three independent culture replicates. Different lowercase letters above bars show significant differences between treatments at $p \leq 0.05$.

All strains were able to release potassium, except for the DE1 strain that likely used it for its own growth. The amount of soluble $\mathrm{K}$ released greatly varied from strain to strain and ranged from $3.8 \mathrm{mg} / \mathrm{L}$ to $216.6 \mathrm{mg} / \mathrm{L}$. Three strains (AZ, AYD and DE2) released a large amount of potassium in the AMM supernatants (>100 mg/L) (Figure 3). The presence of 
large amounts of $\mathrm{K}$ in the supernatant of these strains in the presence of orthoclase simply indicated that the rate of $\mathrm{K}$ released from orthoclase exceeded its rate of consumption for bacterial growth. As expected, strains with the lowest biomass yields (Figure 2) solubilized the smallest amounts of potassium (Figure 3).

Strains AZ and AYD (class II) released the maximal soluble K concentration $(216.6 \mathrm{mg} / \mathrm{L}$ and $155.6 \mathrm{mg} / \mathrm{L}$, respectively), whereas strains BYC and AI (class I) released approximately 2- to 3-fold smaller amounts of soluble $\mathrm{K}$ from orthoclase $(61 \mathrm{mg} / \mathrm{L}$ and $35.8 \mathrm{mg} / \mathrm{L}$, respectively) (Figure 3).

The strain BYC (class I) is of special interest since it was able to release a large amount of $\mathrm{K}$ from orthoclase $(61 \mathrm{mg} / \mathrm{L})$ and its biomass yield was the highest (Figure 3$)$. The strains AYD and DE2 (class II) released over 2-fold more soluble K from orthoclase (155.6 mg/L and $125.4 \mathrm{mg} / \mathrm{L}$, respectively) than the BYC strain (Figure 3). The biomass yield of the strain AI was $14 \%$ lower than that of the strain BYC in similar culture conditions. Interestingly, the strains DE1 (class II) and BX (class III) did not increase the amount of soluble potassium in the culture medium. This suggested that the K-solubilizing ability of these strains was less efficient than that of the others.

\subsection{PH Evolution of the Growth Medium}

The $\mathrm{pH}$ of the growth medium of all strains in orthoclase was between 7.2 and 6.2 at day 1 and stabilized afterwards in most cases at approximately $\mathrm{pH}$ 6.2, except for AI, CYM and AYD strains (Figure 4). This indicated that the solubilization process might involve the excretion of organic acids. The $\mathrm{pH}$ of the medium decreased below 6 for the AI strain from day 3 (Figure 4). The AYD strain released the largest amount of K $(155.6 \mathrm{mg} / \mathrm{L})$ whereas AI released a fair amount of $\mathrm{K}$ from orthoclase $(35.8 \mathrm{mg} / \mathrm{L})$ and CYM released a rather small amount $(5.15 \mathrm{mg} / \mathrm{L})$ (Figure 3). The $\mathrm{pH}$ of the medium of the seven remaining strains (AZ, AYD, DE2, BYC, AV, BP and BX) was similar and stabilized at pH 6 (Figure 4), suggesting their abilities to solubilize $\mathrm{K}$ by organic acid production.

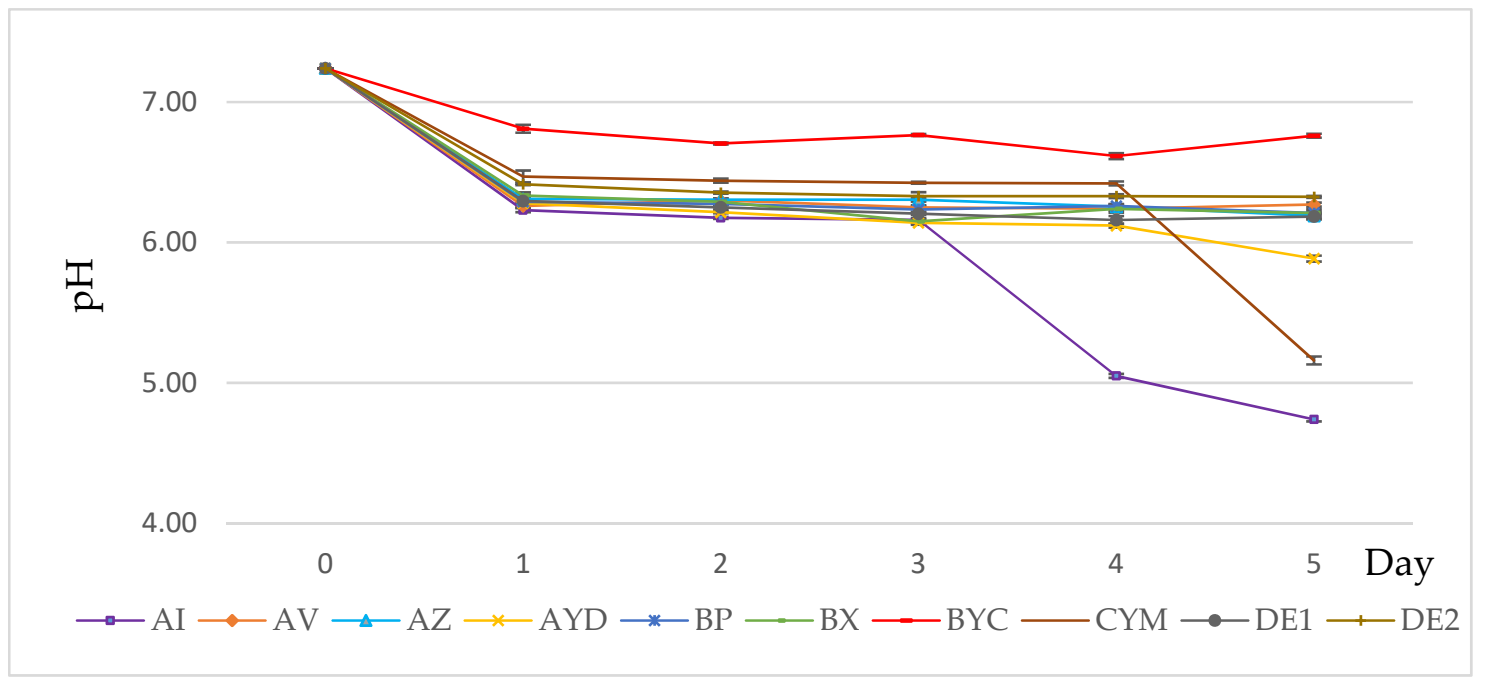

Figure 4. Evolution of the $\mathrm{pH}$ of the medium of the selected Actinomycete strains grown in AMM + orthoclase. Error bars represent standard deviations of the mean values of the results of three independent culture replicates.

\subsection{Indole Acetic Acid (IAA) Production}

The results of IAA production of the 10 selected Streptomyces spp. are shown in Figure 4. IAA production was detected in all strains in significantly different amounts, ranging from 7.9 to $22.3 \mu \mathrm{g} / \mathrm{mL}$. The highest concentration was produced by the CYM and BYC strains $(22.3 \pm 0.1 \mu \mathrm{g} / \mathrm{mL}$ and $19.8 \pm 0.1 \mu \mathrm{g} / \mathrm{mL})$ followed by AV $(16.4 \pm 0.8 \mu \mathrm{g} / \mathrm{mL})$, AYD $16.3 \pm 0.1 \mu \mathrm{g} / \mathrm{mL})$ and DE2 $(16.2 \pm 0.9 \mu \mathrm{g} / \mathrm{mL})$. The lowest values, $7.9 \pm 0.1 \mu \mathrm{g} / \mathrm{mL}$ and $8.8 \pm 1.0 \mu \mathrm{g} / \mathrm{mL}$, were obtained by BP and AZ, respectively (Figure 5). 


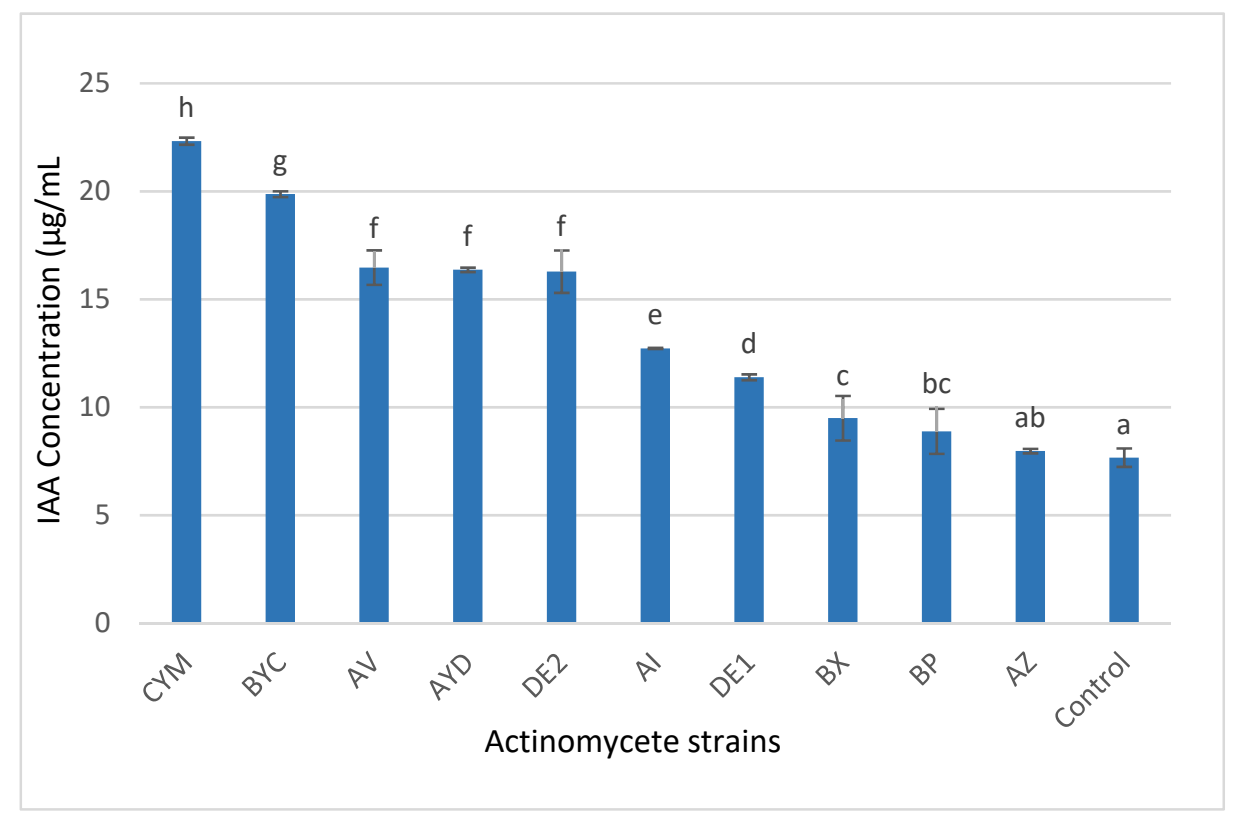

Figure 5. Concentration of indole acetic acid released $(\mu \mathrm{g} / \mathrm{mL})$ in the non-inoculated flasks (control) and in the supernatant of cultures of the ten selected Actinomycete strains grown for $72 \mathrm{~h}$ in liquid LB medium containing L-tryptophan $(1 \mathrm{~g} / \mathrm{L})$. After addition of $2 \mathrm{~mL}$ of Salkowski's reagent, the formation of the pink color indicated the presence of IAA and the IAA concentration produced was estimated by measuring the OD at $530 \mathrm{~nm}$ after $30 \mathrm{~min}$ of incubation in the dark. Error bars represent standard deviations of the mean values of the results of three independent culture replicates. Different lowercase letters above bars shows significant differences between treatments at $p \leq 0.05$.

\subsection{Identification of the Isolated Fungi from the Field}

The result of preliminary identification shows that the three selected isolates (CHAMP1, CHAMP2 and CHAMP3) belong to the genus Fusarium. Macroscopically, most colonies were characterized by their cottony appearance, salmon pigmentation and purple, lilac, light brown, yellow or gray color. Microscopically, colonies were characterized by hyaline hyphae, septate and filamentous; septate macroconidia, fusiform with characteristic appearance of alantoespora, oval microconidia and, in some cases, chlamydoconidia of thick walls.

The fungi sequences of three selected isolates were analyzed using BLAST (http: //www.ncbi.nlm.nih.gov/BLAST/ (accessed on 3 April 2021)). They belonged to the Fusarium genus, bearing an identity of at least $99 \%$ and confirmed our result of preliminary identification.

Nucleotide sequences of the identified fungi were deposited in the GenBank Database (http:/ / www.ncbi.nlm.nih.gov/GenBank/ (accessed on 3 April 2021)), and were assigned accession no. MW824656 (Fusarium equiseti), MW824923 (Fusarium fujikuroi) and MW825349 (Fusarium fujikuroi).

A small subunit ribosomal RNA gene, internal transcribed spacer 1 and $5.8 \mathrm{~S}$ ribosomal RNA gene and internal transcribed spacer 2 sequences (513 nt) of 28 Fusarium species retrieved from GenBank, as well as those of our strains, were used for the construction of a phylogenic tree (Figure 6). Two fungi (CHAMP1 and CHAMP3) were closely related to F. fujikuroi and the isolate CHAMP2 was related to F. equiseti. 


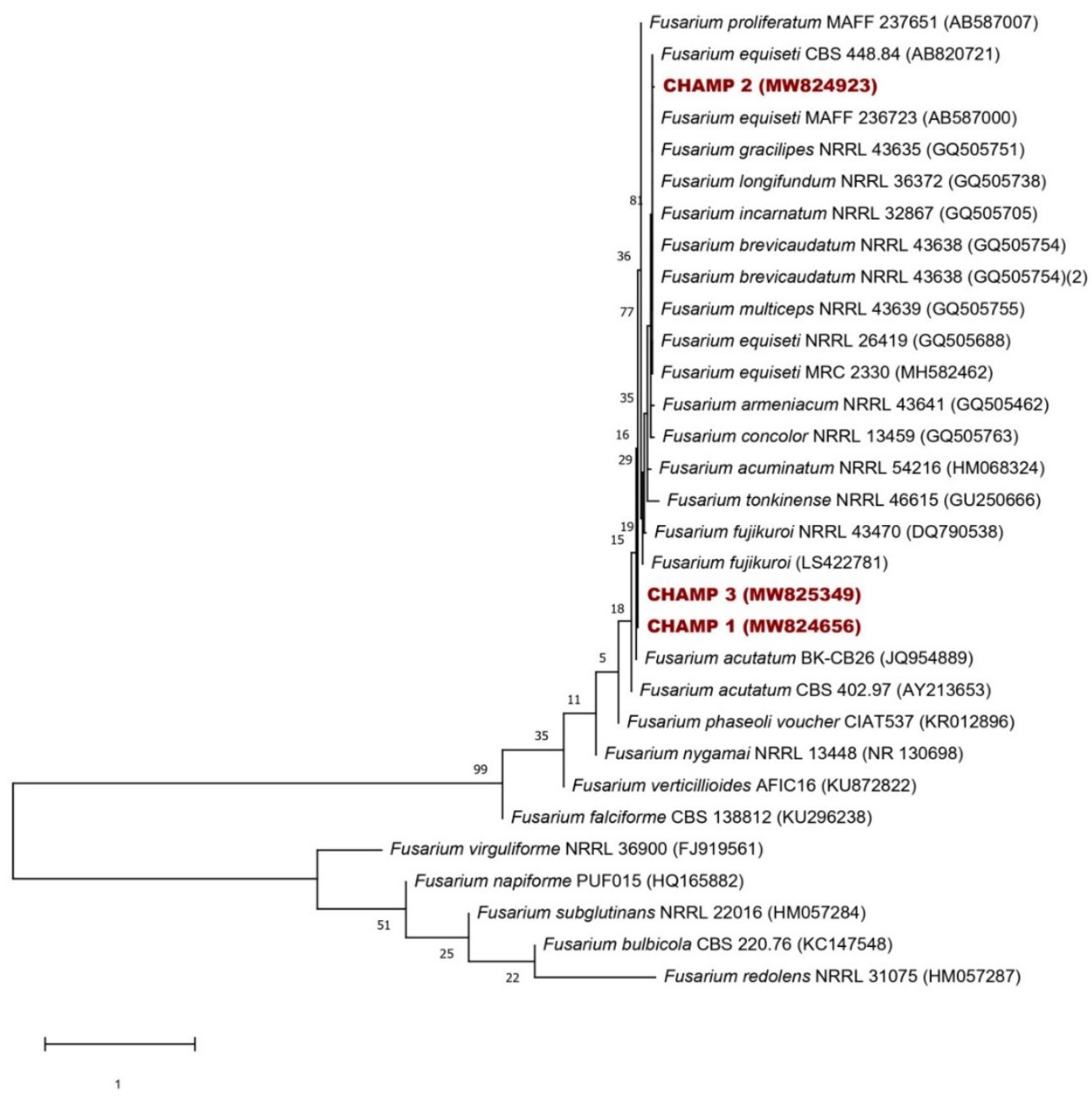

Figure 6. Neighbor-joining phylogenetic tree of the three isolated fungal strains (CHAMP 1, CHAMP 2 and CHAMP 3 ) and 28 Fusarium species based on small subunit ribosomal RNA gene, internal transcribed spacer 1 and 5.8S ribosomal RNA gene, and internal transcribed spacer 2 sequences ( $513 \mathrm{nt}$ ). Numbers at nodes indicate levels of bootstrap support (\%) based on a neighbor-joining analysis of 1000 resampled datasets; only values $>50 \%$ are given. Accession numbers are given in parentheses. Bar marks one nucleotide substitution per site.

\subsection{In Vitro Antagonistic Activity Assays}

We evaluated the antagonistic activity of our 10 selected Streptomyces spp. against the three identified sugar beet rhizoplane fungi, pathogenic bacteria and yeast (Figure 7). All Streptomyces spp. showed an antagonistic activity at different inhibition percentages (PIs). PIs ranged from $6.9 \%$ (BX strain) to $55.4 \%$ (AYD strain). The AYD strain exhibited a significantly higher inhibitory effect (PI) against the identified fungi, two Fusarium fujikuroi (CHAMP1) and F. equiseti (CHAMP2), at $55.4 \% \pm 0.6$ and $43.1 \% \pm 0.2$, respectively (Figure 7), whereas the lowest activity was shown by the AZ strain.

None of the 10 tested Streptomyces isolates showed activity against the Gram-positive Bacillus subtilis or Streptococcus sp., or Gram-negative Pseudomonas aeruginosa. Significant inhibition activity was shown by CYM, DE1 and AZ strains against Staphylococcus aureus. The 10 Streptomyces spp. were not able to limit growth of the Gram-negative bacterium Escherichia coli, except the AYD strain. Only the BYC and AYD strains had a significantly strong inhibitory activity against Salmonella sp. Except the AYD and AV strains, all the tested strains had inhibitory activity against Klebsiella pneumonia. The BYC, BP and DE1 strains produced the largest inhibition zones. Nine out of the ten Streptomyces sp. (except the BX strain) inhibited growth of Candida albicans, and the DE2, CYM and DE1 strains produced the largest inhibition zones (Table 1). 


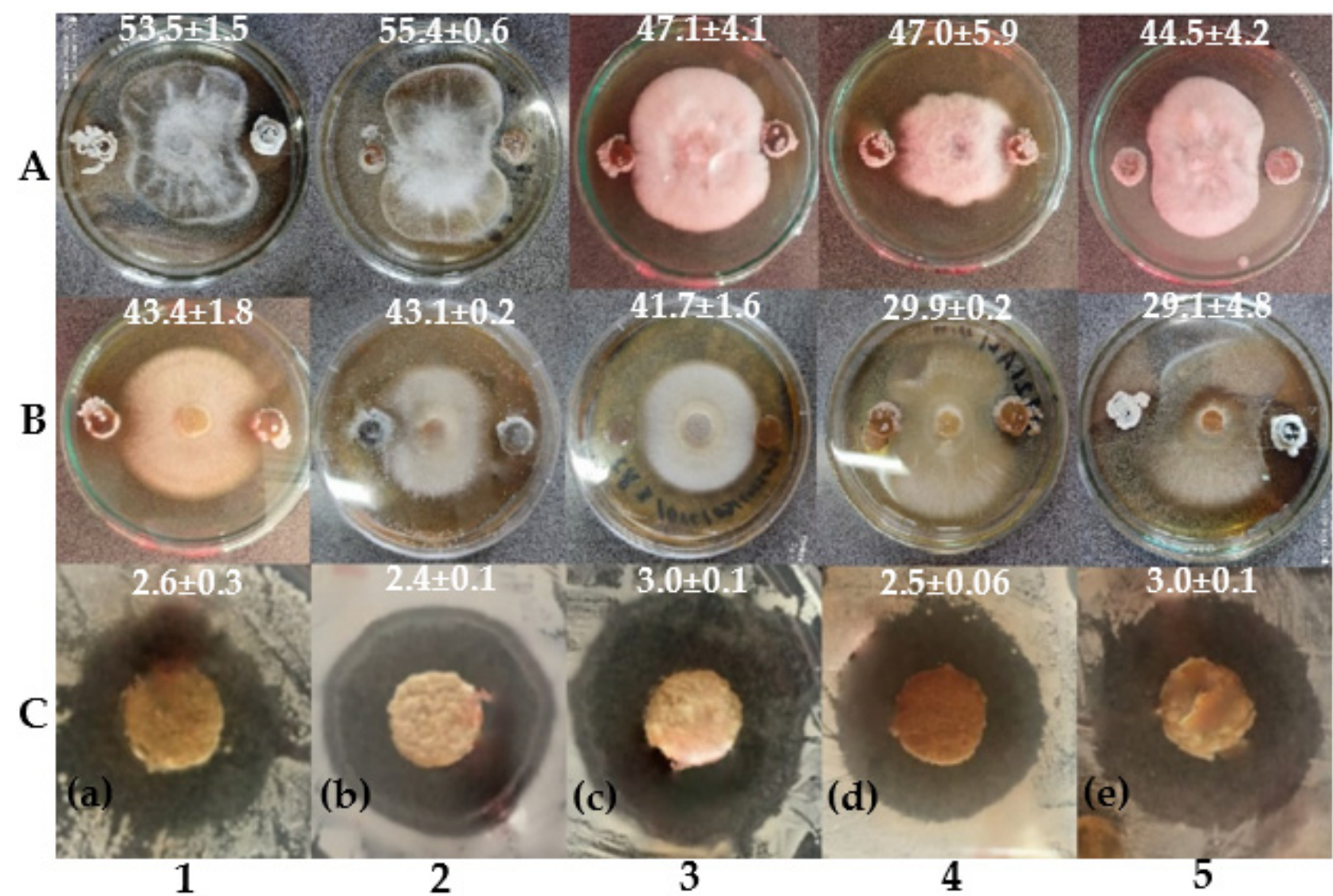

Figure 7. Performance comparison between the five most active Streptomyces spp. (1: DE2; 2: AYD; 3: BYC; 4: AI and 5: AV) against the three isolated phytopathogenic fungi from sugar beet rhizosphere in Beni Mellal, Morocco: (A) Fusarium fujikuroi (CHAMP1) and (B) F. equiseti (CHAMP2); (C) yeast: (a) Candida albicans CCMM/L11; pathogenic bacteria: (b) Escherichia coli CCMM/B4; (c) Salmonella sp. CCMM/B17; (d) Klebsiella pneumonia E40; (e) Staphylococcus aureus CCMM/B2.

Table 1. In vitro antagonistic activities of the ten Streptomyces strains against the three Fusarium isolates from diseased sugar beet roots from Beni Mellal, Morocco: Two Fusarium fujikuroi (CHAMP1; CHAMP3) and F. equiseti (CHAMP2); yeast: Candida albicans CCMM/L11; human pathogenic bacteria: Escherichia coli CCMM/B4; Salmonella sp. CCMM/B17; Klebsiella pneumonia E40; Staphylococcus aureus CCMM/B2; Bacillus subtilis ATCC 9524; Streptococcus sp. CCMM/B24; Pseudomonas aeruginosa CCMM/B90 (zone of inhibition $\pm \mathrm{SD} \mathrm{cm}$ ) (percentage of inhibition $\pm \mathrm{SD} \mathrm{mm}$ ). Different lowercase letters above bars show significant differences between treatments at $p \leq 0.05$.

\begin{tabular}{|c|c|c|c|c|c|c|c|c|}
\hline \multirow{3}{*}{$\begin{array}{l}\text { Streptomyces } \\
\text { Strains }\end{array}$} & \multicolumn{3}{|c|}{ Fungi } & \multirow{2}{*}{$\begin{array}{c}\begin{array}{c}\text { Bacteria } \\
\text { Gram+ }\end{array} \\
\text { S. aureus } \\
\text { CCMM/B2 }\end{array}$} & \multicolumn{3}{|c|}{ Bacteria Gram- } & \multirow{2}{*}{$\begin{array}{c}\text { Yeast } \\
\text { C. albicans } \\
\text { CCMM/L11 }\end{array}$} \\
\hline & CHAMP 1 & CHAMP 2 & CHAMP 3 & & $\begin{array}{l}\text { Salmonella sp. } \\
\text { CCMM/B17 }\end{array}$ & $\begin{array}{l}\text { K. pneumonia } \\
\text { E40 }\end{array}$ & $\begin{array}{c}\text { E. coli } \\
\text { CCMM/B4 }\end{array}$ & \\
\hline & \multicolumn{3}{|c|}{ Percentage of Inhibition (PI \pm SD $\mathbf{m m}$ ) } & \multicolumn{5}{|c|}{ Zone of Inhibition $\pm S D \mathrm{~cm}$} \\
\hline CYM & $41.3 \pm 8.8 \mathrm{~d}$ & $35.4 \pm 3.5$ de & $30.7 \pm 5.7 \mathrm{~b}$ & $2.8 \pm 0.1 \mathrm{e}$ & 0 & $2.7 \pm 0.1 \mathrm{bc}$ & 0 & $2.9 \pm 0.1 \mathrm{~d}$ \\
\hline $\mathrm{BP}$ & $24.2 \pm 1.2 \mathrm{c}$ & $8.2 \pm 7.5 \mathrm{a}$ & $23.8 \pm 5.3 \mathrm{ab}$ & $1.3 \pm 0.0 \mathrm{a}$ & 0 & $3.0 \pm 0.1 \mathrm{~d}$ & 0 & $1.3 \pm 0.1 \mathrm{a}$ \\
\hline DE1 & $20.4 \pm 4.2 \mathrm{bc}$ & $13.7 \pm 7.3 \mathrm{ab}$ & $23.0 \pm 4.3 \mathrm{ab}$ & $2.5 \pm 0.2 \mathrm{~cd}$ & 0 & $2.8 \pm 0.2 \mathrm{c}$ & 0 & $2.6 \pm 0.1 \mathrm{c}$ \\
\hline $\mathrm{AZ}$ & $7.6 \pm 3.4 \mathrm{a}$ & $19.2 \pm 11 \mathrm{abc}$ & $18.5 \pm 2.6 \mathrm{ab}$ & $2.3 \pm 0.2 \mathrm{c}$ & 0 & $2.2 \pm 0.1 \mathrm{a}$ & 0 & $1.7 \pm 0.5 \mathrm{ab}$ \\
\hline $\mathrm{BX}$ & $12.7 \pm 3.3 \mathrm{ab}$ & $7.6 \pm 0.7 \mathrm{a}$ & $6.9 \pm 0.4 \mathrm{a}$ & $2.2 \pm 0.4 \mathrm{c}$ & 0 & $2.3 \pm 0.1 \mathrm{a}$ & 0 & $2.3 \pm 0.3 c$ \\
\hline
\end{tabular}

Finally, the results were combined together to identify the multifaceted strains with the highest potential for sugar beet growth promotion in order to use them for further experiments in field trials (Table 2). 
Table 2. The criteria score for screening of the 10 selected Streptomyces sp. with multifaceted PGP activities from sugar beet rhizospheres in Beni Mellal, Morocco. The numbers in the table represent a score out of 10, assigned to each strain according to its solubilization capacity, antimicrobial activity and the rate of IAA and siderophore release.

\begin{tabular}{|c|c|c|c|c|c|c|c|c|}
\hline $\begin{array}{l}\text { Streptomyces } \\
\text { Strains }\end{array}$ & $\begin{array}{c}\text { Solubilization } \\
\text { of } \mathbf{R P} *, \psi\end{array}$ & $\begin{array}{c}\text { Solubilization } \\
\text { of TCP * }\end{array}$ & $\begin{array}{c}\text { Potassium } \\
\text { Solubilization } \psi\end{array}$ & $\begin{array}{l}\text { Antifungal } \\
\text { Activity } \Psi\end{array}$ & $\begin{array}{c}\text { Antibacterial } \\
\text { Activity }\end{array}$ & $\begin{array}{c}\text { Production } \\
\text { of IAA } \psi\end{array}$ & $\begin{array}{l}\text { Production of } \\
\text { Siderophores * }\end{array}$ & $\begin{array}{l}\text { Final } \\
\text { Score }\end{array}$ \\
\hline BYC & 20 & 9 & 14 & 16 & 4 & 18 & 9 & 90 \\
\hline AYD & 16 & 8 & 18 & 20 & 3 & 14 & 8 & 87 \\
\hline DE2 & 10 & 10 & 16 & 18 & 7 & 12 & 10 & 83 \\
\hline $\mathrm{AZ}$ & 14 & 7 & 20 & 4 & 6 & 2 & 7 & 60 \\
\hline $\mathrm{AI}$ & 12 & 6 & 10 & 14 & 1 & 10 & 6 & 59 \\
\hline CYM & 8 & 2 & 6 & 10 & 10 & 20 & 2 & 58 \\
\hline AV & 4 & 4 & 12 & 12 & 5 & 16 & 4 & 57 \\
\hline BP & 18 & 5 & 8 & 8 & 9 & 4 & 5 & 57 \\
\hline DE1 & 6 & 3 & 2 & 6 & 8 & 8 & 3 & 36 \\
\hline $\mathrm{BX}$ & 2 & 1 & 4 & 2 & 2 & 6 & 1 & 18 \\
\hline
\end{tabular}

* Aallam et al. [40], ${ }^{*}$ criteria score doubled.

\section{Discussion}

In our previous research [40], we successfully isolated 10 Streptomyces spp. and revealed their phosphate solubilization capacities and siderophore production. In this study, we investigated whether these Streptomyces spp. represent multifaceted PGP by testing their abilities to solubilize potassium from orthoclase as the sole $\mathrm{K}$ source and to produce IAA and their inhibitory activities against Fusarium sp., the causal agent of sugar beet root rot in the Beni Mellal region (Morocco).

More than $90 \%$ of $\mathrm{K}$ exists as an insoluble rock form in soils, and the amount of soluble $\mathrm{K}$ is very small [57]. It has become a necessity to isolate and screen K-solubilizing microorganisms in order to improve the amount of soluble $\mathrm{K}$ in soil and to meet the requirements of growing plants. Thus, the results of this study showed that the 10 Streptomyces spp. were able to solubilize $\mathrm{K}$ using AMM with orthoclase as the sole K source. Interestingly, in the AMM broth, the amount of soluble K ranged from $3.8 \mathrm{mg} / \mathrm{L}$ to $216.6 \mathrm{mg} / \mathrm{L}$ after 5 days of cultivation. Similarly, Han et al. [58] reported that Streptomyces rochei and S. sundarbansensis released amounts of K of 7.46 to $13.71 \mathrm{mg} / \mathrm{L}$ in the same conditions. Other studies showed that Streptomyces alboviridis P18, S. griseorubens BC3, S. griseorubens BC10 and Nocardiopsis alba BC11 had the ability to solubilize K in AMM and amounts of K ranged from 2.6 to $41.45 \mathrm{mg} / \mathrm{L}$ after 11 days of cultivation [23]. Reyes-Castillo et al. [59] reported that Bacillus mucilaginosus dissolved $\mathrm{K}$ from motmorillonite, kaolinite and K-feldspar, showing values of 90 to $140 \mathrm{mg} / \mathrm{L}$ after 7 days of cultivation.

Microorganisms have many mechanisms to solubilize $\mathrm{K}$ from a mineral source. Researchers have suggested that this solubilization might be either due to the excretion of protons, $\mathrm{H}+$ or $\mathrm{CO}_{2}$ and organic acids, causing acidification of the external medium, or to the excretion of chelating substances (such as siderophores) that form stable complexes with potassium adsorbents (aluminum, iron and calcium) [57,60-63]. In this research, the $\mathrm{pH}$ of the growth medium of all strains in AMM broth with orthoclase was between 7.2 and 6.2 at day 1 and stabilized afterwards in most cases at approximately pH 6.2, except for the $\mathrm{AI}$ and CYM strains (Figure 2). This indicated that the solubilization process might involve the excretion of organic acids. Interestingly, AI yielded much better biomass (Figure 3) and was shown to excrete siderophores, but not the CYM strain [40], whereas BYC released a rather small amount (2-fold less, $61 \mathrm{mg} / \mathrm{L}$ ). However, this strain produced siderophores and was selected as the best phosphate-solubilizing strain from both RP and TCP [40]. The purification and structural characterization of potentially novel siderophores and/or organic acids are in progress. Our results are in agreement with other investigations performed by Bagyalakshmi et al. [64], which reported that KSB prefer an acidic to neutral range of $\mathrm{pH}$. Moreover, other researchers reported that the production of some different primary proteins and polysaccharides can also control the release of $\mathrm{K}$ from $\mathrm{K}$-bearing minerals [65-67]. In contrast, Dhiman et al. [68] have observed that at $\mathrm{pH} \mathrm{7,} \mathrm{the} \mathrm{strains}$ show the best K solubilization activity in the presence of Proteus mirabilis MG738216. 
Furthermore, the 10 selected Streptomyces spp., except the DE1 strain, had the ability to produce IAA (Figure 4). The CYM, BYC, AV, AYD and DE2 strains were the best IAA producers, with values of more than $15 \mu \mathrm{g} / \mathrm{mL}$ to $22.3 \mu \mathrm{g} / \mathrm{mL}$. According to Djebaili et al. [32], the bacteria with the ability to produce more than $13.0 \mu \mathrm{g} / \mathrm{mL}$ have PGP activity. Similarly, Streptomyces atrovirens showed an interesting growth-promoting activity in groundnut, cotton and maize [69]. Several other studies have demonstrated the ability of Actinomycetes to secret IAA in several other plant rhizospheres $[23,58]$.

Multiple potential PGP activities by the selected 10 Streptomyces spp. were performed by their antagonistic activity against three Fusarium sp. isolated and identified from the infected sugar beet rhizosphere (Figures 1 and 5). In dual culture, S. bellus (AYD) had a higher inhibitory effect against the three fungal causal agents of root rot of sugar beet: Fusarium equiseti and two F. fujikuroi at 55\%, 43\% and 36\%, respectively. Similarly, Getha et al. [70] demonstrated the ability of a Streptomyces sp. to inhibit the growth of Fusarium wilt of banana. Moreover, Streptomyces bikiniensis HD-087 isolated from Hulunbeier grassland soil show a strongly antagonistic activity against Fusarium oxysporum [71]. Streptomyces have also shown an ability to control Fusarium wilt of tomato in greenhouse conditions [72]. According to Yang et al. [73], 60\% of antibiotics used in agriculture are produced by different Streptomyces species. To explain the biocontrol ability of Actinomycetes, many mechanisms have been suggested, such as secreting extracellular cell wall hydrolases [74], production of secondary metabolites [75], inducing plant resistance [76,77], competing for nutrients such as iron (siderophores) in the environment and by producing hydrolytic enzymes, especially chitinase, which degrades the crucial constituent of the fungal cell wall, chitin [78,79].

These results suggest that our selected species, Streptomyces enissocaesilis (BYC), S. bellus (AYD) and S. saprophyticus (DE2), exhibit the highest multifaceted PGPR activities, and they may represent efficient biofertilizers and biocontrol agents (Table 2). Further studies on the effectiveness of their use in controlled pot experiments and in the field are in progress. The use of these endemic selected Streptomyces spp. as both P and K solubilizers, in addition to their biological control ability, could be considered as an innovative pathway to sustainable and ecofriendly agriculture.

Author Contributions: Conceptualization, H.H. and Y.A.; methodology, Y.A. and H.H.; software, Y.A. and S.L.; validation, H.H., S.L., D.D. and M.T.; formal analysis, H.H., S.L., A.S. and M.T.; investigation, Y.A. and H.H.; resources, H.H., A.H., S.L., B.E.M. and D.D.; data curation, Y.A., H.H. and S.L.; writing—original draft preparation, Y.A. and H.H.; writing-review and editing, H.H., M.T., D.D., S.L., A.S., A.H. and B.E.M.; visualization, H.H.; supervision, H.H. and A.H.; project administration, H.H. All authors have read and agreed to the published version of the manuscript.

Funding: This research received no external funding.

Institutional Review Board Statement: Not applicable.

Informed Consent Statement: Not applicable.

Data Availability Statement: The data that support the findings of this study are available from the corresponding author upon reasonable request.

Conflicts of Interest: The authors declare no conflict of interest.

\section{References}

1. Lateef, E.; Abd El-salam, M.; Farrag, A.; Amin, G. Fertilizer Inputs Impact Of Different Bio-Solid Sources On Sugar Beet Yield In Sandy Soil. Int. J. Agric. For. Life Sci. 2019, 3, 106-114.

2. Al Jbawi, E.; Al Raei, A.F.; Ali, A.A.A.; Al Zubi, H. Genotype-Environment Interaction Study in Sugar Beet (Beta vulgaris L.). Int. J. Environ. 2013, 5, 9-19. [CrossRef]

3. FAOSTAT Food and Agricultural Organization Statistics. Available online: http://www.fao.org/faostat/en/\#data/QC (accessed on 15 April 2021).

4. ORMVAT Office Régional de Mise en Valeur Agricole de Tadla. Available online: www.ormvat.ma (accessed on 3 February 2021).

5. Redani, L. Competitivite, Valorisation des Ressources et Objectifs de Sécurité Alimentaire pour la Filière Sucrière au Maroc. Ph.D Thesis, University of Liège, Gembloux, Belgium, 2015. 
6. Cakmak, I. The role of potassium in alleviating detrimental effects of abiotic stresses in plants. J. Plant Nutr. Soil. Sci. 2005, 168, 521-530. [CrossRef]

7. Aksu, G.; Altay, H. The Effects of Potassium Applications on Drought Stress in Sugar Beet. Sugar Tech. 2020, 22, 1092-1102. [CrossRef]

8. Barlog, P.; Grzebisz, W.; Peplinski, K.; Szczepaniak, W. Sugar Beet Response to Balanced Nitrogen Fertilization with Phosphorus and Potassium. Bulg. J. Agric. Sci. 2013, 19, 1311-1318.

9. Hanafy, E.; El-Bana, A.; Yasin, M.; El-Naggar, N. Impact of Planting Density, Nitrogen and Potassium Fertilizer Levels on Yield and Quality of Sugar Beet. Zagazig J. Agric. Res. 2019, 46, 2133-2143. [CrossRef]

10. Abdel-Motagally, F.M.; Attia, K.K. Response of Sugar Beet Plants to Nitrogen and Potassium Fertilization in Sandy Calcareous Soil. Int. J. Agric. Biol. 2016, 11, 695-700.

11. Sparks, D.L.; Huang, P.M. Physical Chemistry of Soil Potassium. In Potassium in Agriculture; Mounson, R.D., Ed.; American Society of Agronomy, Crop Science Society of America and Soil Science Society of America: Madison, WI, USA, 1985; pp. 201-276.

12. Sugumaran, P.; Janarthanam, B. Solubilization of Potassium Containing Minerals by Bacteria and Their Effect on Plant Growth. World J. Agric. Sci. 2007, 3, 350-355.

13. Li, Y.; Li, Q.; Guan, G.; Chen, S. Phosphate solubilizing bacteria stimulate wheat rhizosphere and endosphere biological nitrogen fixation by improving phosphorus content. PeerJ 2020, 8, 1-15. [CrossRef] [PubMed]

14. Wang, Z.; Chen, Z.; Xu, Z.; Fu, X. Effects of phosphate-solubilizing bacteria and N2-fixing bacteria on nutrient uptake, plant growth, and bioactive compound accumulation in Cyclocarya paliurus (Batal.) Iljinskaja. Forests 2019, 10, 772. [CrossRef]

15. Baghel, V.; Thakur, J.K.; Yadav, S.S.; Manna, M.C.; Mandal, A.; Shirale, A.O.; Sharma, P.; Sinha, N.K.; Mohanty, M.; Singh, A.B.; et al. Phosphorus and Potassium Solubilization From Rock Minerals by Endophytic burkholderia sp. Strain FDN2-1 in Soil and Shift in Diversity of Bacterial Endophytes of Corn Root Tissue with Crop Growth Stage. Geomicrobiol. J. 2020, 1-14. [CrossRef]

16. Ben-laouane, R.; Baslam, M.; Ait-el-mokhtar, M.; Anli, M.; Boutasknit, A.; Ait-Rahou, Y.; Toubali, S.; Mitsui, T. Potential of Native Arbuscular Mycorrhizal Fungi, Rhizobia, and/or Green Compost as Alfalfa (Medicago sativa) Enhancers under Salinity. Microorganisms 2020, 8, 1695. [CrossRef]

17. Sattar, A.; Naveed, M.; Ali, M.; Zahir, Z.A.; Nadeem, S.M.; Yaseen, M.; Singh, S.V.; Farooq, M.; Singh, R.; Rahman, M.; et al. Perspectives of potassium solubilizing microbes in sustainable food production system: A review. Appl. Soil. Ecol. 2018, 133, 146-159. [CrossRef]

18. Meena, V.S.; Maurya, B.R.; Verma, J.P. Does a rhizospheric microorganism enhance K+ availability in agricultural soils? Microbiol. Res. 2014, 169, 337-347. [CrossRef]

19. Ali, A.M.; Awad, M.Y.M.; Hegab, S.A.; Abd, A.M.; Gawad, E.; Eissa, M.A.; Ali, A.M.; Awad, M.Y.M.; Hegab, S.A.; Abd, A.M. Effect of potassium solubilizing bacteria (Bacillus cereus) on growth and yield of potato. J. Plant Nutr. 2020, 44, 411-420. [CrossRef]

20. Xiao, Y.; Wang, X.; Chen, W.; Huang, Q. Isolation and identification of three potassium- solubilizing bacteria from rape rhizospheric soil and their effects on ryegrass. Geomicrobiol. J. 2017, 34, 873-880. [CrossRef]

21. Sun, F.; Ou, Q.; Wang, N.; Ou, Y.; Li, N.; Peng, C. Isolation and identification of potassium-solubilizing bacteria from Mikania micrantha rhizospheric soil and their effect on M. micrantha plants. Glob. Ecol. Conserv. 2020, 23, 1-27. [CrossRef]

22. Saha, M.; Maurya, B.R.; Meena, S.; Bahadur, I.; Kumar, A. Identification and characterization of potassium solubilizing bacteria (KSB) from Indo-Gangetic Plains of India. Biocatal. Agric. Biotechnol. 2016, 7, 202-209. [CrossRef]

23. Boubekri, K.; Soumare, A.; Mardad, I.; Lyamlouli, K.; Hafidi, M.; Ouhdouch, Y.; Kouisni, L. The Screening of Potassium- and Phosphate-Solubilizing Actinobacteria and the Assessment of Their Ability to Promote Wheat Growth Parameters. Microorganisms 2021, 9, 470. [CrossRef]

24. Hillnhütter, C.; Mahlein, A.; Sikora, R.A.; Oerke, E. Field Crops Research Remote sensing to detect plant stress induced by Heterodera schachtii and Rhizoctonia solani in sugar beet fields. F. Crop. Res. J. 2011, 122, 70-77. [CrossRef]

25. Wolfgang, A.; Zachow, C.; Müller, H.; Grand, A.; Temme, N.; Tilcher, R.; Berg, G. Understanding the Impact of Cultivar, Seed Origin, and Substrate on Bacterial Diversity of the Sugar Beet Rhizosphere and Suppression of Soil-Borne Pathogens. Front. Plant Sci. 2020, 11, 1-15. [CrossRef]

26. De Lucchi, C.; Piergiorgio, S.; Linda, H.; Mitch, M.; Lee, P.; De, B.M.; Chiara, B.; Marco, B.; Sella, L.; Concheri, G. Molecular markers for improving control of soil-borne pathogen Fusarium oxysporum in sugar beet. Euphytica 2017, 213, 1-14. [CrossRef]

27. Harveson, R.M.; Rush, C.M. Genetic Variation among Fusarium oxysporum Isolates from Sugar Beet as Determined by Vegetative Compatibility. Plant Dis. 1997, 81, 85-88. [CrossRef]

28. Harveson, R.M.; Rush, C.M. Characterization of Fusarium Root Rot Isolates from Sugar Beet by Growth and Virulence at Different Temperatures and Irrigation Regimes. Plant Dis. 1998, 82, 1039-1042. [CrossRef]

29. Hanson, L.E.; Hill, A.L.; Jacobsen, B.J.; Panella, L. Response of Sugarbeet Lines to Isolates of Fusarium oxysporum f. sp. Betae from the United States. J. Sugar Beet Res. 2009, 46, 11-26. [CrossRef]

30. Jacobsen, B.J. Root Rot Diseases of Sugar Beet. Proc. Nat. Sci. Matica Srp. Novi. Sad. 2006, 9-19. [CrossRef]

31. Errakhi, R.; Lebrihi, A.; Barakate, M. In vitro and in vivo antagonism of actinomycetes isolated from Moroccan rhizospherical soils against Sclerotium rolfsii: A causal agent of root rot on sugar beet (Beta vulgaris L.). J. Appl. Microbiol. 2009, 107, 672-681. [CrossRef] [PubMed]

32. Djebaili, R.; Pellegrini, M.; Smati, M.; Del Gallo, M.; Kitouni, M. Actinomycete Strains Isolated from Saline Soils: Plant-GrowthPromoting Traits and Inoculation Effects on Solanum lycopersicum. Sustainability 2020, 12, 4617. [CrossRef] 
33. Yoolong, S.; Kruasuwan, W.; Phạm, H.T.; Jaemsaeng, R.; Jantasuriyarat, C.; Thamchaipenet, A. Modulation of salt tolerance in Thai jasmine rice (Oryza sativa L. venezuelae cv KDLM105) by Streptomyces ATCC 10712 expressing ACC deaminase. Sci. Rep. 2019, 9, 1-10. [CrossRef]

34. Gebauer, L.; Bouffaud, M.; Ganther, M.; Yim, B.; Vetterlein, D.; Smalla, K.; Buscot, F.; Heintz-buschart, A.; Tarkka, M.T. Soil Texture, Sampling Depth and Root Hairs Shape the Structure of ACC Deaminase Bacterial Community Composition in Maize Rhizosphere. Front. Microbiol. 2021, 12, 1-12. [CrossRef] [PubMed]

35. Elbendary, A.A.; Hessain, A.M.; El, M.D.; Seida, A.A.; Moussa, I.M.; Mubarak, A.S.; Kabli, S.A.; Hemeg, H.A.; Kamal, J.; Jakee, E. Isolation of antimicrobial producing Actinobacteria from soil samples. Saudi J. Biol. Sci. 2017, 25, 44-46. [CrossRef]

36. Olanrewaju, O.S.; Glick, B.R.; Babalola, O.O. Mechanisms of action of plant growth promoting bacteria. World J. Microbiol. Biotechnol. 2017, 33, 1-16. [CrossRef]

37. Hamdali, H.; Bouizgarne, B.; Hafidi, M.; Lebrihi, A.; Virolle, M.J.; Ouhdouch, Y. Screening for rock phosphate solubilizing Actinomycetes from Moroccan phosphate mines. Appl. Soil. Ecol. 2008, 38, 12-19. [CrossRef]

38. Hamdali, H.; Lebrihi, A.; Monje, M.C.; Benharref, A.; Hafidi, M.; Ouhdouch, Y.; Virolle, M.J. A Molecule of the Viridomycin Family Originating from a Streptomyces griseus-Related Strain Has the Ability to Solubilize Rock Phosphate and to Inhibit Microbial Growth. Antibiotics 2021, 10, 72. [CrossRef] [PubMed]

39. Evangelista-Martínez, Z. Isolation and characterization of soil Streptomyces species as potential biological control agents against fungal plant pathogens. World J. Microbiol. Biotechnol. 2014, 30, 1639-1647. [CrossRef]

40. Aallam, Y.; Dhiba, D.; Lemriss, S.; Souiri, A.; Karray, F.; El Rasafi, T.; Saïdi, N.; Haddioui, A.; El Kabbaj, S.; Virolle, M.J.; et al. Isolation and characterization of phosphate solubilizing Streptomyces sp. Endemic from sugar beet fields of the beni-mellal region in morocco. Microorganisms 2021, 9, 914. [CrossRef] [PubMed]

41. Meena, V.S.; Maurya, B.R.; Verma, J.P.; Aeron, A.; Kumar, A.; Kim, K.; Bajpai, V.K. Potassium solubilizing rhizobacteria (KSR): Isolation, identification, and K-release dynamics from waste mica. Ecol. Eng. 2015, 81, 340-347. [CrossRef]

42. Hu, X.; Chen, J.; Guo, J.; Hangzhou, X. Two Phosphate- and Potassium-solubilizing Bacteria Isolated from Tianmu Mountain, Zhejiang, China. World J. Microbiol. Biotechnol. 2006, 22, 983-990. [CrossRef]

43. Liu, D.F.; Lian, B.; Wang, B. Solubilization of potassium containing minerals by high temperature resistant Streptomyces sp. isolated from earthworm's gut. Acta Geochim. 2016, 35, 262-270. [CrossRef]

44. Sachdev, D.P.; Chaudhari, H.G.; Kasture, V.M.; Dhavale, D.D.; Chopade, B.A. Isolation and characterization of indole acetic acid (IAA) producing Klebsiella pneumonia strains from rhizosphere of wheat (Triticum aestivum) and their effect on plant growth. Indian J. Exp. Biol. 2009, 47, 993-1000.

45. Loper, J.E.; Schroth, M.N. Influence of Bacterial Sources of Indole3-acetic Acid on Root Elongation of Sugar Beet. Physiol. Biochem. 1986, 76, 386-389. [CrossRef]

46. Barakat, A.; Ennaji, W.; Krimissa, S.; Bouzaid, M. Heavy metal contamination and ecological-health risk evaluation in peri-urban wastewater-irrigated soils of Beni-Mellal city (Morocco). Int. J. Environ. Health Res. 2019, 30, 372-387. [CrossRef]

47. Chenaoui, M.; Amar, M.; Benkhemmar, O.; El Aissami, A.; Arahou, M.; Rhazi, L. Isolation and characterization of fungi from sugar beet roots samples collected from Morocco. J. Mater. Environ. Sci. 2017, 8, 3962-3967.

48. Leaw, S.; Chang, H.; Sun, H.; Barton, R.; Bouchara, J.; Chang, T. Identification d'espèces de levure médicalement importantes par analyse de séquence des régions d'espaceur transcrites internes. J. Clin. Microbiol. 2006, 44, 693-699. [CrossRef]

49. Vainio, E.J.; Hantula, J. Direct analysis of wood-inhabiting fungi using denaturing gradient gel electrophoresis of amplified ribosomal DNA. Myco Res. 2000, 104, 927-936. [CrossRef]

50. Saitou, N.; Nei, M. The Neighbor-joining Method: A New Method for Reconstructing Phylogenetic Trees. Mol. Biol. Evol. 1987, 4, 406-425. [CrossRef]

51. Felsenstein, J. Phylogenies and the Comparative Method. Am. Nat. 1985, 125, 1-15. [CrossRef]

52. Kimura, M. A simple method for estimating evolutionary rates of base substitutions through comparative studies of nucleotide sequences. J. Mol. Evol. 1980, 16, 111-120. [CrossRef] [PubMed]

53. Kumar, S.; Stecher, G.; Li, M.; Knyaz, C.; Tamura, K. MEGA X: Molecular evolutionary genetics analysis across computing platforms. Mol. Biol. Evol. 2018, 35, 1547-1549. [CrossRef] [PubMed]

54. Bauer, A.W.; Kirby, M.; Sherris, J.C.; Turck, M. Antibiotic susceptibility testing by a standardized single disk method. Am. J. Clin. Pathol. 1966, 45, 493-496. [CrossRef]

55. Hamdali, H.; Hafidi, M.; Joe, M.; Ouhdouch, Y. Growth promotion and protection against damping-off of wheat by two rock phosphate solubilizing actinomycetes in a P-deficient soil under greenhouse conditions. Appl. Soil Ecol. 2008, 40, 510-517. [CrossRef]

56. Karimi, E.; Safaie, N.; Shams-Baksh, M.; Mahmoudi, B. Bacillus amyloliquefaciens SB14 from rhizosphere alleviates Rhizoctonia damping-off disease on sugar beet. Microbiol. Res. 2016, 192, 221-230. [CrossRef] [PubMed]

57. Prasad, M.; Srinivasan, R.; Chaudhary, M.; Choudhary, M.; Jat, L.K. Plant Growth Promoting Rhizobacteria (PGPR) for Sustainable Agriculture: Perspectives and Challenges. In PGPR Amelioration in Sustainable Agriculture; Singh, K.A., Kumar, A., Singh, K.P., Eds.; Woodhead: Sawston, UK, 2019; pp. 129-157. [CrossRef]

58. Han, D.; Wang, L.; Luo, Y. Isolation, identification, and the growth promoting effects of two antagonistic actinomycete strains from the rhizosphere of Mikania micrantha Kunth. Microbiol. Res. 2018, 208, 1-11. [CrossRef] 
59. Reyes-castillo, A.; Gerding, M.; Oyarzúa, P.; Zagal, E.; Gerding, J. Plant growth-promoting rhizobacteria able to improve NPK availability: Selection, identification and effects on tomato growth. Chil. J. Agric. Res. 2019, 79, 473-485. [CrossRef]

60. Etesami, H.; Emami, S.; Alikhani, H.A. Potassium solubilizing bacteria (KSB): Mechanisms, promotion of plant growth, and future prospects-A review. J. Soil Sci. Plant Nutr. 2017, 17, 897-911. [CrossRef]

61. Yuan, Z.S.; Liu, F.; Zhang, G.F. Characteristics and biodiversity of endophytic phosphorus- and potassium solubilizing bacteria in moso bamboo (Phyllostachys edulis). Acta Biol. Hung. 2015, 66, 449-459. [CrossRef]

62. Dominguez-Nunez, J.A.; Benito, B.; Berrocal-Lobo, M.; Albanesi, A. Mycorrhizal Fungi: Role in the Solubilization of Potassium. In Potassium Solubilizing Microorganisms for Sustainable Agriculture; Meena, V., Maurya, B., Verma, J., Meena, R., Eds.; Springer: New Delhi, India, 2016; pp. 77-98. [CrossRef]

63. Bashir, Z.; Zargar, M.Y.; Vishwakarma, D.K. Potassium-solubilizing Microorganisms for Sustainable Agriculture. In Applied Agricultural Practices for Mitigating Climate Change; Kumar, R., Singh, P.V., Jhajharia, D., Mirabbasi, R., Eds.; Taylor \& Francis: New York, NY, USA, 2019; pp. 17-28.

64. Bagyalakshmi, B.; Ponmurugan, P.; Balamurugan, A. Potassium solubilization, plant growth promoting substances by potassium solubilizing bacteria (KSB) from southern Indian Tea plantation soil. Biocatal. Agric. Biotechnol. 2017, 12, 116-124. [CrossRef]

65. Liu, W.; Xu, X.; Wu, X.; Yang, Q.; Luo, Y.; Christie, P. Decomposition of silicate minerals by Bacillus mucilaginosus in liquid culture. Environ. Geochem. Health 2006, 28, 133-140. [CrossRef]

66. Sheng, X.F.; He, L.Y. Solubilization of potassium-bearing minerals by a wild-type strain of Bacillus edaphicus and its mutants and increased potassium uptake by wheat. Can. J. Microbiol. 2006, 72, 66-72. [CrossRef] [PubMed]

67. Shelobolina, E.; Xu, H.; Konishi, H.; Kukkadapu, R.; Wu, T.; Blöthe, M.; Roden, E. Microbial Lithotrophic Oxidation of Structural Fe (II) in Biotite. Appl. Environ. Microbiol. 2012, 78, 5746-5752. [CrossRef]

68. Dhiman, S.; Dubey, R.C.; Baliyan, N.; Kumar, S.; Maheshwari, D.K. Application of potassium-Solubilising Proteus mirabilis MG738216 inhabiting cattle dung in improving nutrient use efficiency of Foeniculum vulgare Mill. Environ. Sustain. 2019, 2, 401-409. [CrossRef]

69. Reddy, K.R.K.; Jyothi, G.; Sowjanya, C.; Kusumanjali, K.; Malathi, N.; Reddy, K.R.N. Plant Growth-Promoting Actinomycetes: Mass Production, Delivery systems, and commercialization. In Plant Growth Promoting Actinobacteria; Subramaniam, G., Arumugam, S., Rajendran, V.G., Eds.; Springer: Singapore, 2016; pp. 1-298. [CrossRef]

70. Getha, K.; Vikineswary, S.; Wong, W.H.; Seki, T.; Ward, A.; Goodfellow, M. Evaluation of Streptomyces sp. strain g10 for suppression of Fusarium wilt and rhizosphere colonization in pot-grown banana plantlets. J. Ind. Microbiol. Biotechnol. 2005, 32, 24-32. [CrossRef] [PubMed]

71. Zhao, S.; Du, C.; Tian, C. Suppression of Fusarium oxysporum and induced resistance of plants involved in the biocontrol of Cucumber Fusarium Wilt by Streptomyces bikiniensis HD-087. World J. Microbiol. Biotechnol. 2012, 28, 2919-2927. [CrossRef]

72. Anitha, A.; Rabeeth, M. Control of Fusarium Wilt of Tomato by Bioformulation of Streptomyces griseus in Green House Condition. Afr. J. Basic. Appl. Sci. 2009, 1, 9-14.

73. Yang, Y.; Zhang, S.W.; Li, K.T. Antagonistic activity and mechanism of an isolated Streptomyces corchorusii stain AUH-1 against phytopathogenic fungi. World J. Microbiol. Biotechnol. 2019, 35, 1-9. [CrossRef]

74. Li, Y.; He, F.; Lai, H.; Xue, Q. Mechanism of in vitro antagonism of phytopathogenic Scelrotium rolfsii by actinomycetes. Eur. J. Plant Pathol. 2017, 149, 299-311. [CrossRef]

75. Soares, A.C.F.; Sousa, C.D.S.; Garrido, M.D.S.; Perez, J.O.; De Almeida, N.S. Soil streptomycetes with in vitro activity against the yam pathogens Curvularia eragrostides and Colletotrichum gloeosporioides. Braz. J. Microbiol. 2006, 37, 456-461. [CrossRef]

76. Li, Y.; Guo, Q.; He, F.; Li, Y.; Xue, Q.; Lai, H. Biocontrol of Root Diseases and Growth Promotion of the Tuberous Plant Aconitum carmichaelii Induced by Actinomycetes Are Related to Shifts in the Rhizosphere Microbiota. Microb. Ecol. 2020, 79, 134-147. [CrossRef]

77. Kurth, F.; Mailänder, S.; Bönn, M.; Feldhahn, L.; Herrmann, S.; Große, I.; Buscot, F.; Schrey, S.D.; Tarkka, M.T. StreptomycesInduced resistance against oak powdery mildew involves host plant responses in defence, photosynthesis and secondary metabolism pathways. Mol. Plant Microbe Interact. 2014, 27, 891-900. [CrossRef] [PubMed]

78. Musa, Z.; Ma, J.; Egamberdieva, D.; Abdelshafy, M.O.A.; Abaydulla, G.; Liu, Y.; Li, W.J.; Li, L. Diversity and Antimicrobial Potential of Cultivable Endophytic Actinobacteria Associated With the Medicinal Plant Thymus roseus. Front. Microbiol. $2020,11$. [CrossRef] [PubMed]

79. Singh, S.P.; Gupta, R.; Gaur, R.; Srivastava, A.K. Antagonistic Actinomycetes Mediated Resistance in Solanum lycopersicon Mill. Against Rhizoctonia solani Kühn. Proc. Natl. Acad. Sci. India Sect. B Biol. Sci. 2015, 87, 789-798. [CrossRef] 